\title{
SELECTIVE LASER SINTERING TECHNOLOGY IS TO BE USED IN ORDER TO OBTAIN AVIATION UNIT APPLICATION
}

\author{
${ }^{1}$ Oksana VODENNIKOVA, ${ }^{2}$ Mykyta KOVAL, ${ }^{3}$ Sergii VODENNIKOV \\ 'Zaporizhzhia National University, o.s.vodennikova@gmail.com \\ 2JSC «Motor Sich», 2,3im.billyblock@gmail.com, \\ ${ }^{3}$ National University «Zaporizhzhia Polytechnic», s vodennikov@i.ua
}

https://doi.org/10.37904/metal.2021.4156

\begin{abstract}
According to the three-dimensional digital model additive production as a method of product manufacturing allows creating complex-profile structures with high mechanical and operational specifications. Metal products structuring in accordance with the process of their production is of considerable interest. The paper presents a comprehensive study of the technological parameter influence on selective laser sintering (SLS) technology on the properties of samples of heat-resistant nickel alloy Inconel 718. A comparative analysis of the mechanical properties of the Inconel 718 alloy, obtained by sintering powders produced in Great Britain («LPW») and China («Sino Euro»), with the regulatory characteristics of ASM 5662M (for alloy Inconel 718) and TU 14-1-3905-85 (for alloy EP718-VD) is conducted. The dependence of mechanical and heat-resistant properties of Inconel 718 alloy from the direction of the part's growth, horizontal direction $X Y$ and vertical direction Z, has been established. The microstructure of Inconel 718 alloy samples was studied before and after heat treatment. Using Unigraphics NX 7.5, a 3D-model of aviation parts was built. In particular, they are a turbine nozzle and fuel swirler for the needs of the combustion chamber of an aircraft engine. The 3Dprinting of the parts for aviation application is characterized by a smaller number of technological operations. Costs for equipment and additional machining are reduced and product prototyping is simplified. In its turn, it allows reducing the mass of parts by 10-20\% compared to their metal analogues, discarded by machining.
\end{abstract}

Keywords: Additive technologies, selective laser sintering, Inconel 718, 3D-printing, 3D-model

\section{INTRODUCTION}

Important advantages in the introduction of additive technologies are the ability to reduce the weight of products, simplify their design, reduce the cost of time and money for development, manufacture and operation [1]. Today, additive technology can be implemented in three stages of production - models, prototypes and parts that meet all the requirements of design documentation for complex technical systems for full service life [2]. With the help of selective laser sintering (SLS) and selective laser melting (SLM) technology, precise metal products are created for work as a part of units and units of responsible purpose (for example, aerospace), which gradually replaces traditional methods of their production [3]. Thus, for the manufacture of combustion chambers, turbine blades, rocket engines and nuclear reactors is widely used heat-resistant alloy based on Inconel 718. The alloy has high creep resistance, high temperature strength, good resistance to high temperature corrosion and good weldability $[4,5]$.

Mechanisms that provide high cyclic fatigue of the Inconel 718 alloy obtained by laser powder melting are considered in [6]. The authors of [7] paid attention to the influence of surface roughness and build-up thickness on the fatigue characteristics of the Inconel 718 alloy at $650^{\circ} \mathrm{C}$. The influence of SLM process parameters on the microstructure and mechanical properties of Inconel 718 is the subject of research [8]. The question of studying the microstructure of the Inconel 718 alloy made by the SLM method under different heat treatment 
is disclosed in [9]. The study of the microstructure and cyclic behavior of corrosion of the Inconel 718 alloy applied by laser under different heat treatment conditions is devoted to the work of [10]. The relationship between the parameters of the SLM process and the microstructure in the creation of quality products from the alloy Inconel 718 is described in [11]. In [12] a comprehensive study of the influence of technological parameters of the SLM process on the structure and properties of samples of Inconel 718 alloy is presented. The authors present the results of studies of mechanical properties of compact samples made at different layer thicknesses, both in the initial state and after hot isostatic pressing heat treatment.

\section{RESEARCH METHODOLOGY}

Studies of the Inconel 718 heat-resistant alloy technology obtaining were carried out in the conditions of JSC «Motor Sich» (Ukraine) by SLS on a 3D printer EOS M400, which has a printing accuracy of $100 \mu \mathrm{m}$ and a print area of $400 \times 400 \times 400 \mathrm{~mm}$. The samples were subjected to hot isostatic pressing followed by heat treatment, in accordance with the requirements of the technical conditions for aerospace materials ASM 5662M. Powders made in Great Britain («LPW») and China («Sino Euro») were used as starting powder materials.

The chemical composition of the alloy Inconel 718 was determined by spectral and chemical analysis. Determination of the mechanical properties of the samples was performed as follows: long-term strength was determined on the Instron $\mathrm{M} 3$ at a temperature of $800{ }^{\circ} \mathrm{C}$ and a constant applied load of $206 \mathrm{MPa}$; ultimate stress $\left(\sigma_{u}\right), 0.2 \%$ proof stress $\left(\sigma_{0,2}\right)$, relative extension $(\delta)$ and relative narrowing $(\Psi)$ were tested on a rupture machine ZDMY30; toughness (KCU) was determined on impact samples with a concentrator of type $U$, tested on a pendulum dill Instron SI-1 M; Brinell hardness was determined on a LECOAMH-43 hardness tester. To determine the mechanical properties, samples of cylindrical (diameter $14 \mathrm{~mm}$ ) and rectangular (with a cross section of $16 \mathrm{~mm}$ ) shapes were made. Five specimens grown in both the horizontal direction $X Y$ and the vertical direction $Z$ were tested. Heat-resistant properties of the samples were determined at a temperature of $650{ }^{\circ} \mathrm{C}$ and an applied load of $687 \mathrm{MPa}$. Structural studies were performed on undigested sections on a microscope «Axio Observer. DIm».

Approbation of SLS technology to obtain aviation parts was carried out by 3D-printing of the cooled nozzle of the turbine and the swirler for the needs of the combustion chamber of the aircraft engine.

\section{RESULTS OF THE STUDY}

Analysis of the chemical composition of the heat-resistant alloy Inconel 718, obtained by the SLS method from powders produced in Great Britain («LPW») and China ( Sino Euro»), showed that the composition complies with ASM 5662M for Inconel 718 and TU 14-1-3905 -85 for EP718-VD alloy.

Analysis of the mechanical properties of the alloy Inconel 718, obtained from the powder company «LPW», showed that both in the horizontal direction XY (Table 1) and in the vertical direction Z (Table 2), the properties meet the standards of ASM 5662M.

Considering the properties of the alloy Inconel 718 , obtained from the powder company «Sino Euro» found that in comparison with the values of horizontal samples ( $X Y$ direction) for vertical samples ( $Z$ direction) is characterized by some decrease in strength characteristics (in particular, $\sigma_{u}, \sigma_{0,2}-$ within normal limits ASM $5662 \mathrm{M}$ ) and increase of plastic characteristics (in particular, $\delta, \Psi$ and $\mathrm{KCU}$ ) (Table 2). It is also observed in the vertical direction of exceeding the toughness of the alloy Inconel 718 by $10.25 \mathrm{~J} / \mathrm{cm}^{2}$ in comparison with the norms of TU 14-1-3905-85 for the alloy EP718-VD (Table 3).

Analyzing the heat-resistant properties of cylindrical heat-treated samples of Inconel 718 alloy, it was found that (Table 3): time to fracture of samples from powders of «LPW» and «Sino Euro» in the vertical direction is 1.9 and 1.4 times higher than in the horizontal direction; for samples from «Sino Euro» powder, compared to «LPW» powder samples, the time to failure is 3.2 and 2.4 times longer in the horizontal and vertical directions, 
respectively.

Table 1 Mechanical properties of the alloy Inconel 718, obtained from powders of different production, and the standard ASM 5662M in the horizontal direction XY

\begin{tabular}{|c|c|c|c|c|c|c|}
\hline $\begin{array}{c}\text { № } \\
\text { of sample }\end{array}$ & $\begin{array}{c}\sigma_{\mathrm{u}}, \\
\mathrm{Mpa}\end{array}$ & $\begin{array}{l}\sigma_{0,2} \\
\mathrm{MPa} \\
\end{array}$ & $\begin{array}{l}\delta \\
\%\end{array}$ & $\begin{array}{l}\Psi \\
\%\end{array}$ & $\begin{array}{l}\mathrm{KCU} \\
\mathrm{kJ} / \mathrm{m}^{2}\end{array}$ & $\begin{array}{c}\text { Brinell } \\
\text { hardness, } \mathrm{HB}\end{array}$ \\
\hline \multicolumn{7}{|c|}{ Powder of the firm «LPW» } \\
\hline 1 & 1490 & 1292 & 22,5 & 33,4 & 38.0 & 429 \\
\hline 2 & 1492 & 1298 & 22,0 & 32,3 & 37.5 & 444 \\
\hline 3 & 1488 & 1278 & 22,0 & 36,6 & 31.0 & 444 \\
\hline 4 & 1481 & 1260 & 21,0 & 30,0 & - & - \\
\hline 5 & 1493 & 1286 & 22,0 & 36,3 & - & - \\
\hline \multicolumn{7}{|c|}{ Powder of the firm «Sino Euro» } \\
\hline 1 & 1506 & 1312 & 15,2 & 18,5 & 120.1 & 430 \\
\hline 2 & 1506 & 1316 & 15,6 & 15,4 & 134.8 & 444 \\
\hline 3 & 1502 & 1310 & 20,0 & 18,8 & 137.8 & 444 \\
\hline 4 & 1512 & 1325 & 15,2 & 15,0 & - & - \\
\hline 5 & 1509 & 1323 & 16,0 & 18,7 & - & - \\
\hline \multicolumn{7}{|c|}{ Norms of AMS 5662M } \\
\hline & $\geq 1276$ & $\geq 1034$ & $\geq 12$ & $\geq 15$ & - & $\geq 331$ \\
\hline
\end{tabular}

Table 2 Mechanical properties of Inconel 718 alloy obtained from powders of different production and standards ASM 5662M and TU 14-1-3905-85 in the vertical direction Z

\begin{tabular}{|c|c|c|c|c|c|c|}
\hline $\begin{array}{c}\text { № } \\
\text { of sample }\end{array}$ & $\begin{array}{l}\sigma_{\mathrm{u}} \\
\mathrm{Mpa}\end{array}$ & $\begin{array}{l}\sigma_{0,2} \\
\mathrm{MPa}\end{array}$ & $\begin{array}{l}\delta \\
\%\end{array}$ & $\begin{array}{l}\Psi \\
\%\end{array}$ & $\begin{array}{l}\mathrm{KCU}, \\
\mathrm{kJ} / \mathrm{m}^{2}\end{array}$ & $\begin{array}{c}\text { Brinell } \\
\text { hardness, HB }\end{array}$ \\
\hline \multicolumn{7}{|c|}{ Powder of the firm "LPW» } \\
\hline 1 & 1408 & 1210 & 24.0 & 42.2 & - & - \\
\hline 2 & 1408 & 1197 & 23.5 & 39.4 & - & - \\
\hline 3 & 1408 & 1193 & 29.0 & 42.4 & - & - \\
\hline 4 & 1402 & 1209 & 26.5 & 42.2 & - & - \\
\hline 5 & 1414 & 1200 & 24.0 & 42.3 & - & - \\
\hline \multicolumn{7}{|c|}{ Powder of the firm «Sino Euro» } \\
\hline 1 & 1425 & 1243 & 20.0 & 18.7 & 13.3 & 461 \\
\hline 2 & 1428 & 1237 & 18.8 & 21.9 & 13.75 & 444 \\
\hline 3 & 1432 & 1243 & 12.4 & 10.9 & 12.5 & 461 \\
\hline 4 & 1433 & 1251 & 15.6 & 18.3 & - & - \\
\hline 5 & 1431 & 1200 & 16.4 & 18.5 & - & - \\
\hline \multicolumn{7}{|c|}{ Norms of AMS 5662M } \\
\hline & $\geq 1241$ & $\geq 1034$ & $\geq 10$ & $\geq 12$ & - & $\geq 331$ \\
\hline \multicolumn{7}{|c|}{ Norms of TU 14-1-3905-85 } \\
\hline
\end{tabular}




\begin{tabular}{|l|l|l|l|l|l|l|}
\hline & $\geq 1250$ & $\geq 700$ & $\geq 12$ & $\geq 14$ & $\geq 3.5$ & $363-293$ \\
\hline
\end{tabular}

Table 3 Comparison of heat-resistant properties of the alloy Inconel 718, obtained from powders of different production, and the norms of ASM 5662M and TU 14-1-3905-85

\begin{tabular}{|l|c|c|}
\hline \multirow{2}{*}{ Characteristic } & \multicolumn{2}{|c|}{ Time to fracture, $\mathbf{h}$} \\
\cline { 2 - 3 } & Powder of the firm «LPW» & Powder of the firm «Sino Euro» \\
\hline Horizontal direction XY & $49 . .3$ & 158.3 \\
\hline Vertical direction Z & 94.4 & 224.0 \\
\hline Norms of AMS 5662M & \multicolumn{2}{|c|}{$\geq 23,0$} \\
\hline Norms of TU 14-1-3905-85 & \multicolumn{2}{|c|}{$\geq 60,0$} \\
\hline
\end{tabular}

It should be noted that by changing the parameters of manufacturing parts by SLS it is easier to regulate the structure of metal products in the process of their production in comparison with products obtained by casting and forging. It was found that the microstructure of samples from Inconel 718 alloy grown using SLS technology from «Sino Euro» powder (Figure 1), after heat treatment (along the impact sample) is dense, homogeneous and characterized by fine-grained structure with the presence of macrograins elongated in the direction growth of the sample. Metallographic studies revealed the presence of insignificant microporosity (both in the horizontal direction $X Y$ and in the vertical direction $Z$ ) with a pore size of up to $15 \mu \mathrm{m}$ (Figure 2).

The process of additive cultivation of structural elements of gas turbine engines (in particular, cooled turbine nozzle and swirler for the combustion chamber of the aircraft engine) involves the transfer of a virtual geometric model to the equipment, which then turns it into a real product. SLS technology is used for rapid prototyping of parts, ie as an accelerated method of creating test parts before starting production with the use of machining or replacement of used and broken parts.

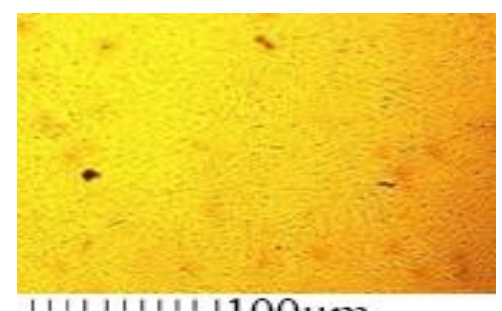

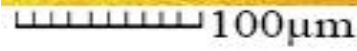

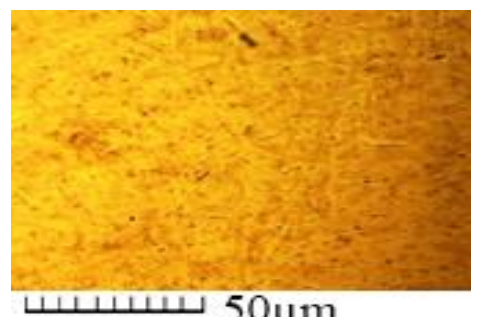

$50 \mu \mathrm{m}$

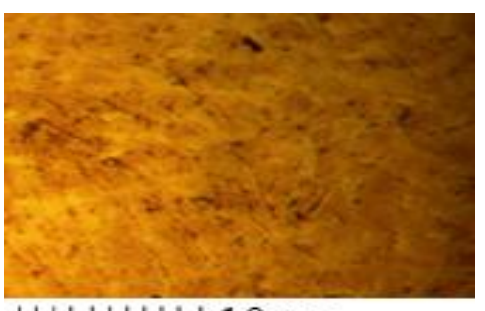

س山س山س $10 \mu \mathrm{m}$

Figure 1 Microstructure of heat-treated samples of Inconel 718 alloy grown with SLS technology from «Sino Euro» powder
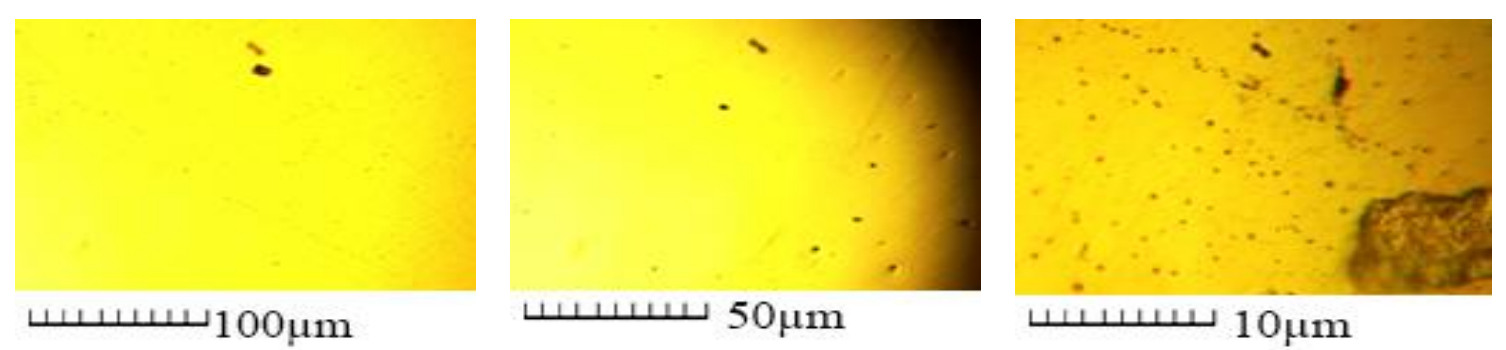

Figure 2 Porosity of heat-treated samples of the alloy Inconel 718, grown using SLS technology from powder company «Sino Euro»

Considering the possibilities of growing SLS technology with a cooled turbine nozzle and vortex for the needs of the combustion chamber of the aircraft engine, a 3D-model of aviation parts was built using Unigraphics NX 7.5. This allows you to model the desired detail in the directions $X, Y, Z$ and see it in different projections 
(Figure 3 and Figure 4). The values of geometric dimensions of the serial part, temperature regime of the unit, heat resistance, heat resistance, thermal conductivity of the alloy and others were used as initial data for the construction of the 3D-model.
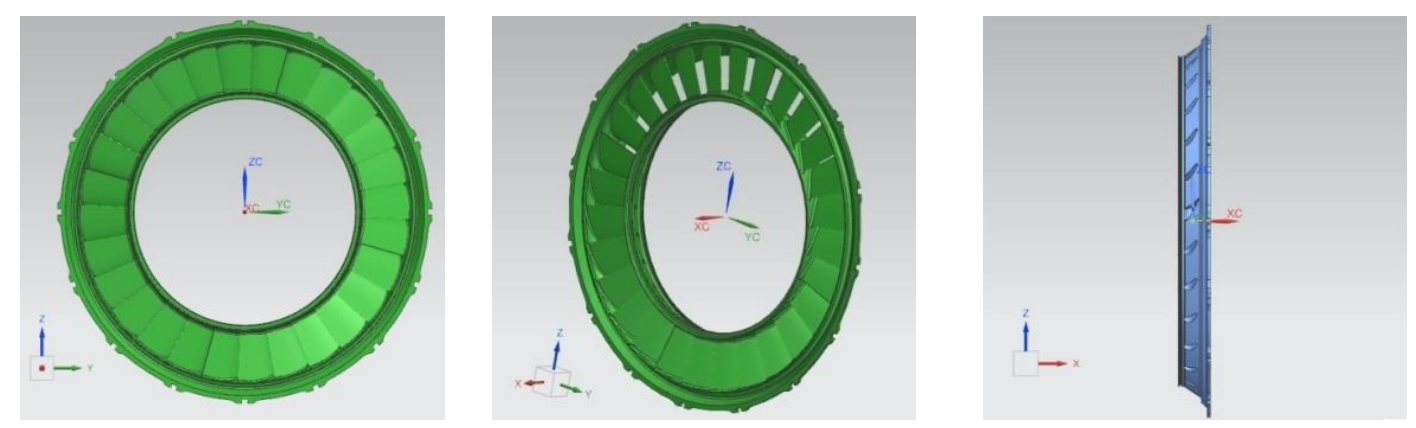

Figure 3 3D-model for the cooled turbine nozzle apparatus production with the help of SLS technology

It is established that the process of 3D-printing of aviation parts (Figure 5) is characterized by a smaller number of technological operations (reduced equipment costs and additional machining) and simplifies product prototyping. The cooled nozzle apparatus of the turbine (Figure 5, a) and the vortex for the needs of the combustion chamber of the aircraft engine (Figure 5, b) grown by means of 3D-printing also have 12-20\% less mass in comparison with their metal analogues.
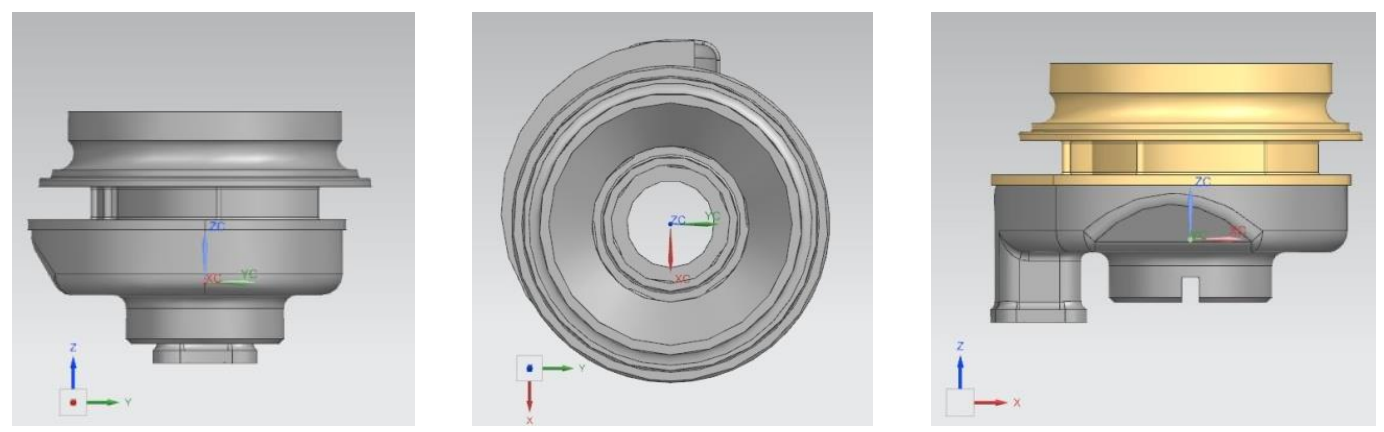

Figure 4 3D-model for the production of swirlers obtained by using SLS
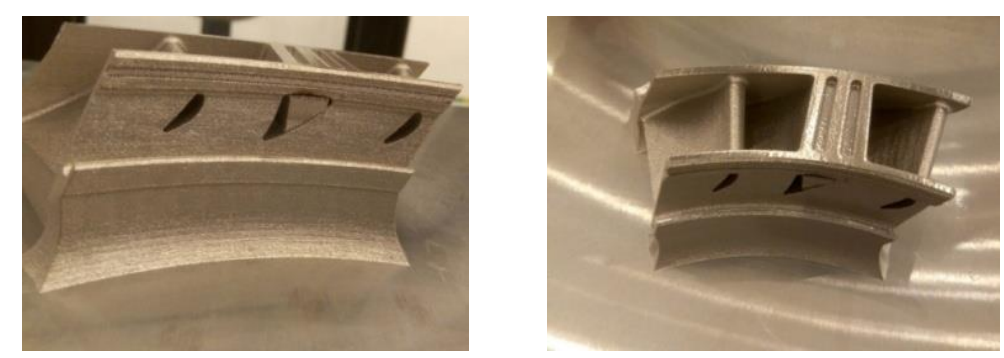

a
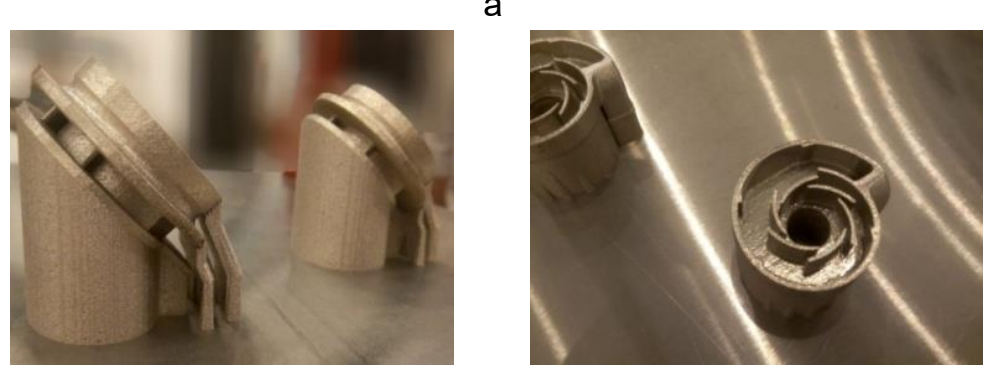

$b$

Figure 5 Aviation spare parts obtained by using SLS technology out of Inconel 718 alloy: a - sector of the 
turbine nozzle apparatus; $b$ - swirler

\section{CONCLUSION}

Comparative analysis of Inconel 718 mechanical properties alloy, obtained by the technology of selective laser sintering of powders produced in Great Britain («LPW») and China («Sino Euro») with normative characteristics ASM 5662M (for Inconel 718 alloy) and TU 14-1 -3905-85 (for alloy EP718-VD), showed that the samples grown in the vertical direction $Z$ is characterized by a slight decrease in strength characteristics and increase in plastic characteristics compared to the values of samples grown in the horizontal direction $X Y$.

Heat-resistant properties analysis of samples from Inconel 718 alloy, obtained by in the horizontal direction $\mathrm{XY}$ and in the vertical direction Z, showed their compliance with AMS 5662M.

It was found that the microstructure of Inconel 718 alloy samples is dense after heat treatment along with the impact sample, homogeneous and characterized by a fine-grained structure with the presence of macrograins elongated in the direction of sample growth. Both in the horizontal direction $X Y$ and in the vertical direction $Z$ there is a slight microporosity with a pore size up to $15 \mu \mathrm{m}$.

The possibility of obtaining of aviation spare parts, cooled nozzle of the turbine and swirlers, namely, out of Inconel 718 alloy with the help of SLS technology, which have 12-20\% less weight compared to their metal analogs, obtained by machining, is showed.

\section{REFERENCES}

[1] MAGERRAMOVAM, L.A, NOZHNITSKY, YU.A., VOLKOV, S.A., VOLKOV, M.E., CHEPURNOV, V.ZH., BELOV, S.V., VERBANOV, I.S., ZAIKIN, S.V. Prospects of application of additive technologies to develop parts and components of gas turbine engines and ramjets. Vestnik of Samara University Aerospace and Mechanical Engineering. [online]. 2019, vol 18, no. 3, pp. 81-98. Available from: https://doi.org/10.18287/2541-7533-2019-183-81-98.

[2] KABLOVM, E. N. The additive technologies are the dominant of national technological initiative. Intellekt $i$ tehnologii. 2015, vol 2, no. 11, pp. 52-55.

[3] ADZHAMSKIY, S.V., KONONENKO, A.A., PODOLSK, R.V. The use of SLM technology in parts and assemblies for aerospace purposes. In: Proceedings. Young scientists 2020 - from theory to practice: XI International Conference of Young Scientists. 12 March 2020, pp. 6-9.

[4] YUAN, H., LIU, W.C. Effect of the $\delta$ phase on the hot deformation behavior of Inconel 718. Mater. Sci. Eng. A. 2005, vol. 408, no. 1-2. pp. 281-289.

[5] ASM Metals Hand Book V. 2. Properties and Selection: Nonferrous Alloys and Special-Purpose Materials. ASM International. 2002, p. 1328.

[6] WATRING, D.S. CARTER, K.C., CROUSE, D., RAEYMAEKERS, B., SPEAR, A.D. Mechanisms driving highcycle fatigue life of as-built Inconel 718 processed by laser powder bed fusion. Materials Science and Engineering. [online]. 22 July 2019, vol. 761, p. 137993. Available from:

https://doi.org/10.1016/i.msea.2019.06.003.

[7] WAN, H.Y., LUO, Y.W., ZHANG, B., SONG, Z.M, WANG, L.Y., ZHOU, Z.J., LI, C.P., CHEN, G.F., ZHANG, G.P. Effects of surface roughness and build thickness on fatigue properties of selective laser melted Inconel 718 at 650 ${ }^{\circ} \mathrm{C}$. International Journal of Fatigue. [online]. August 2020, vol. 137, p. 105654. Available from: https://doi.org/10.1016/.i.jfatigue.2020.105654.

[8] MCLOUTH, T.D., WITKIN, D.B., BEAN, G.E., SITZMAN, S.D., ADAMS, P.M., LOHSER, J.R., YANG, J.-M., ZALDIVAR, R.J. Variations in ambient and elevated temperature mechanical behavior of IN718 manufactured by selective laser melting via process parameter control. Materials Science and Engineering. [online]. 7 April 2020, vol. 780, p. 139184. Available from: https://doi.org/10.1016/j.msea.2020.139184.

[9] LIU, P., SUN, S., CAO, M., GONG, J., HU, J. Microstructural evolution and phase transformation on the X-Y surface of Inconel $718 \mathrm{Ni}$-based alloys fabricated by selective laser melting under different heat treatment. High 
Temperature Materials and Processes. [online]. September 2018, vol. 38(2019). Available from: https://doi:10.1515/htmp-2017-0182.

[10] ZHANG, J., ZHANG, Q., ZHUANG, Y., KOVALENKO, V., YAO, J. Microstructures and cyclic hot corrosion behavior of laser deposited Inconel 718 alloy under different heat treatment conditions. Optics \& Laser Technology. [online]. March 2021, vol. 135, p.106659. Available from: https://doi:10.1016/i.optlastec.2020.106659.

[11] ADZHAMSKIY, S.V. Implementation of SLM - technologies for the manufacture of samples from Inconel 718 heatresistant alloy, used in aviation-space technology. Aerospace technic and technology. [online]. 2019, no 2, pp. 69-75. Available from: https://doi:10.32620/aktt.2019.2.09.

[12] SUFIYAROV, V.SH., BORISOV, E.V., POLOZOV I.A., MASAILO, D.V. Control of structure formation in selective laser melting process. Tsvetnye Metally. [online]. 2018, no. 7. pp. 68-74. Available from: https://doi:10.17580/tsm.2018.07.11. 